\title{
Fungal Sensitivity to and Enzymatic Degradation of the Phytoanticipin $\alpha$-Tomatine
}

\author{
Robert W. Sandrock and Hans D. VanEtten
}

Department of Plant Pathology, University of Arizona, Tucson 85721.

Current address of R. W. Sandrock: Department of Plant Pathology, Cornell University, Ithaca, NY 14853.

Accepted for publication 15 October 1997.

\begin{abstract}
Sandrock, R. W., and VanEtten, H. D. 1998. Fungal sensitivity to and enzymatic degradation of the phytoanticipin $\alpha$-tomatine. Phytopathology $88: 137-143$

$\alpha$-Tomatine, synthesized by Lycopersicon and some Solanum species, is toxic to a broad range of fungi, presumably because it binds to $3 \beta$ hydroxy sterols in fungal membranes. Several fungal pathogens of tomato have previously been shown to be tolerant of this glycoalkaloid and to possess enzymes thought to be involved in its detoxification. In the current study, 23 fungal strains were examined for their ability to degrade $\alpha$-tomatine and for their sensitivity to this compound and two breakdown products, $\beta_{2}$-tomatine and tomatidine. Both saprophytes and all five nonpathogens of tomato tested were sensitive, while all but two tomato patho-
\end{abstract}

ABSTRACT

Many of the class of compounds known as saponins have antimicrobial and insecticidal properties and are considered to be protective agents against potential pathogens and insects $(2,17)$. Saponins are steroidal or triterpenoid compounds that are generally glycosylated at one end of the molecule, possess soap-like properties in water, and have hemolytic and cholesterol-binding properties (27). One member of this group, $\alpha$-tomatine (Fig. 1), is a steroidal glycoalkaloid found in most organs of the tomato plant at concentrations observed to be inhibitory to microbes in vitro, except in ripe fruit where the compound is normally not detectable (15).

Since concentrations of this compound can accumulate at up to $5 \%$ of the fresh weight of tomato tissue (19), it would appear to be a potent barrier to microbial infection. However, the importance of $\alpha$-tomatine and other phytoanticipins (preformed inhibitory compounds [39]) as a general barrier to microbial infection has been circumstantial, and conflicting data exist for the direct involvement of $\alpha$-tomatine in plant resistance. One clear aspect of past research is the observation that fungal pathogens of tomato are generally more tolerant to this phytoanticipin than nonpathogens of tomato and saprophytes (2), suggesting that tomato pathogens have evolved specific means to circumvent this chemical barrier.

Previous research has shown that $\alpha$-tomatine owes it toxic properties to its ability to interact with $3 \beta$-hydroxy sterols (34). Tolerance to $\alpha$-tomatine has been proposed to arise from either membrane characteristics of the fungus or the ability of the fungus to enzymatically detoxify this compound (2). Mutants of Nectria haematococca mating population VI whose membranes were reduced in sterol content were more tolerant to $\alpha$-tomatine (8). Moreover, Pythiaceous fungi such as Pythium and Phytophthora species do

Corresponding author: H. D. VanEtten; E-mail address: vanetten@ag.arizona.edu

Publication no. P-1997-1208-02R

(C) 1998 The American Phytopathological Society gens (Stemphylium solani and Verticillium dahliae) were tolerant of $\alpha$-tomatine $(50 \%$ effective dose $>300 \mu \mathrm{M})$. Except for an isolate of Botrytis cinerea isolated from grape, no degradation products were detected when saprophytes and nonpathogens were grown in the presence of $\alpha$-tomatine. All tomato pathogens except Phytophthora infestans and Pythium aphanidermatum degraded $\alpha$-tomatine. There was a strong correlation between tolerance to $\alpha$-tomatine, the ability to degrade this compound, and pathogenicity on tomato. However, while $\beta_{2}$-tomatine and tomatidine were less toxic to most tomato pathogens, these breakdown products were inhibitory to some of the saprophytes and nonpathogens of tomato, suggesting that tomato pathogens may have multiple tolerance mechanisms to $\alpha$-tomatine.

Additional keywords: glucosidase, nondegradative tolerance, saponin.

not produce $3 \beta$-hydroxy sterols and are relatively tolerant of $\alpha$ tomatine (36). However, when sterols are exogenously supplied to these organisms, they readily incorporate the sterols into the membrane and become sensitive to $\alpha$-tomatine (36). Thus, the membrane characteristics of fungi can directly affect their sensitivity to this saponin.

Enzymatic removal of one or more sugars from the tetrasaccharide moiety of $\alpha$-tomatine has also been shown to restrict its binding to $3 \beta$-hydroxy sterols, thus reducing the toxicity of the compound (3). Hydrolysis of the $\beta-1,2-D$ glucosyl bond, resulting in the release of D-glucose with the formation of $\beta_{2}$-tomatine (Fig. 1A), has been reported for Verticillium albo-atrum (26) and Septoria lycopersici (1). Hydrolysis of all four glycosidic linkages, releasing the four monosaccharides and the aglycone tomatidine, has been observed for Alternaria solani (33), while Botrytis cinerea and Fusarium oxysporum f. sp. lycopersici produce an enzyme that cleaves the $\beta$-1-D galactosidic linkage, releasing the tetrasaccharide moiety as a single unit $(16,24,40)$. Enzymatic alteration of the alkaloid aglycone tomatidine has been documented, but no pathogens have been reported to possess this ability $(4,32)$.

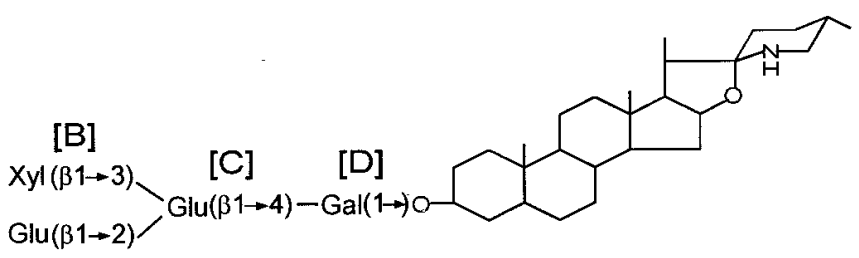

[A]

Fig. 1. Structure of $\alpha$-tomatine ( $O$ - $\beta$-D-glucopyranosyl-(1,2 glu)- $O$ - $\beta$-D-xylopyranosyl-(1,3 glu)- $O$ - $\beta$-D-glucopyranosyl-(1,4 gal)- $\beta$-D-galactopyranosyltomatidine). $\beta_{1}$-Tomatine lacks the sugar $[\mathrm{B}] ; \beta_{2}$-tomatine lacks the sugar $[\mathrm{A}] ; \gamma$-tomatine does not have either sugar $[\mathrm{A}]$ or $[\mathrm{B}] ; \delta$-tomatine does not have sugars $[\mathrm{A}],[\mathrm{B}]$, or $[\mathrm{C}]$; and tomatidine lacks all four sugars. 
Although definitive evidence is lacking regarding the importance of $\alpha$-tomatine detoxification in pathogenicity by tomato pathogens, the importance of the detoxification of the oat saponin avenacin in pathogenicity has recently been demonstrated. Gaeumannomyces graminis var. avenae, a root pathogen, produces an enzyme that hydrolyzes the $\beta-1,2-$ and $\beta-1,4$-linked D-glucose molecules from the triterpenoid avenacin, resulting in a less toxic compound $(7,37)$. The gene encoding the avenacinase enzyme was cloned, and avenacinase-deficient mutants of G. graminis var. avenae were constructed using transformation-mediated gene disruption methods (5). These mutants were no longer pathogenic on oats, which produce avenacin in roots, but retained pathogenicity on wheat, a host that does not produce this saponin. These results provide direct evidence for the involvement of avenacin in plant disease resistance and demonstrate that avenacinase is a pathogenicity trait for G. graminis var. avenae.

As a preliminary step to determine the importance of $\alpha$-tomatine tolerance and detoxification for pathogenicity on tomato, 12 tomato pathogens, 7 pathogens of other nontomato hosts, and 2 saprophytic fungi were tested for their in vitro sensitivity to $\alpha$ tomatine and its derivatives and for their ability to degrade $\alpha$-tomatine. In addition, the inducibility of the $\alpha$-tomatine-degrading enzymes was evaluated in one tomato pathogen (A. solani) and ergosterol mutants of Neurospora crassa were tested for sensitivity to $\alpha$-tomatine and its derivatives to determine if an organism altered in its sterol composition would also be altered in its sensitivity to these compounds.

\section{MATERIALS AND METHODS}

Strains and media. Fungal isolates used in this study are listed in Table 1. Isolates that are indicated as tomato pathogens in Table 2 were originally isolated from tomato. All isolates were grown at $24^{\circ} \mathrm{C}$ except for $P$. infestans, which was grown at $18^{\circ} \mathrm{C}$. Aspergillus nidulans was grown on Aspergillus medium (44). N. crassa was grown on Vogel's medium (41). Magnaporthe grisea was grown on oatmeal agar (38). S. solani was grown on cornmeal agar (Difco Laboratories, Detroit). P. infestans was grown on rye $\mathrm{B}$ medium (6). All other isolates were grown on V8 agar medium
( $200 \mathrm{ml}$ of $\mathrm{V} 8$ juice, $2 \mathrm{~g}$ of $\mathrm{CaCO}_{3}$, and $20 \mathrm{~g}$ of agar per liter). All strains except Pythium aphanidermatum and $P$. infestans were stored as glycerol stocks at $-80^{\circ} \mathrm{C}$.

Bioassay for sensitivity of fungi to $\alpha$-tomatine, $\beta_{2}$-tomatine, and tomatidine. $\alpha$-Tomatine and tomatidine were purchased from Sigma Chemical Co. (St. Louis). $\beta_{2}$-Tomatine was produced by incubating $50 \mathrm{ml}$ of $2.5 \mathrm{mM} \alpha$-tomatine with $25 \mathrm{mM}$ sodium acetate ( $\mathrm{pH} 5.0)$ in the presence of purified $\beta_{2}$-tomatinase (31) for $4 \mathrm{~h}$ at $37^{\circ} \mathrm{C}$. The reaction was checked for completion by thin-layer chromatography (TLC). The solution was then passed through a $0.2-\mu \mathrm{m}$ filter (Nalgene, Rochester, NY) and heated to $60^{\circ} \mathrm{C}$ for $1 \mathrm{~h}$ to inactivate the enzyme. Stocks of $\alpha$-tomatine, $\beta_{2}$-tomatine, and tomatidine were kept as $2.5 \mathrm{mM}$ solutions in $25 \mathrm{mM}$ sodium acetate, $\mathrm{pH}$ 5.0.

Fungi were tested for their sensitivity to $\alpha$-tomatine, $\beta_{2}$-tomatine, and tomatidine by measuring the radius of mycelial colonies grown on medium supplemented with these compounds. All media were adjusted to $\mathrm{pH} 5.0$ with acetic acid prior to autoclaving. Because of the dilution of the media by the addition of the compounds, the media were made at a $1.4 \times$ concentration. Compounds were added to the media after autoclaving. Bioassay plates contained $2 \mathrm{ml}$ of solid medium in a $10 \times 35-\mathrm{mm}$ petri dish containing $0,20,50,100,200,400,800$, and $1,000 \mu \mathrm{M}$ of the compound tested except for those used for $N$. crassa wild type and ergosterol-deficient mutants, which contained 0, 20, 60, 90, 120, $180,240,500$, and $1,000 \mu \mathrm{M}$ of the compound tested. An agar plug (6 $\mathrm{mm}$ diameter) was taken from the edge of an actively growing colony, the mycelial side was placed on the medium at the edge of the dish, and radial growth was measured every $24 \mathrm{~h}$ for 3 to 5 days. Three plates were used for each treatment. The values obtained when the mycelium had advanced approximately $75 \%$ across the plate on medium containing no $\alpha$-tomatine were used to calculate percent inhibition by the test compounds. The concentration of compound that gave $50 \%$ inhibition $\left(\mathrm{ED}_{50}\right)$ of radial growth was extrapolated from these values using the NLIN procedure for nonlinear regression (SAS Institute, Cary, NC). The negative exponential equation $y=b_{0} \cdot\left[1-e^{(-b 1 \cdot x)}\right]$, in which $y$ equals the percent inhibition and $x$ equals the concentration of the compound tested, was used for the nonlinear regression analysis.

TABLE 1. Fungal strains used in this study

\begin{tabular}{|c|c|}
\hline Fungal isolate & Provider \\
\hline Alternaria alternata (Fr.:Fr.) Keissl. \#100ss & D. Gilchrist, Univ. of California, Dept. of Plant Pathol., Davis \\
\hline A. alternata (Fr.:Fr.) f. sp. lycopersici Grogan et al. T507a & D. Gilchrist \\
\hline A. solani Sorauer T519a & P. Shoemaker, N. Carolina Mountain Hortic. Crops Res. \& Ext., Fletcher \\
\hline Verticillium dahliae Kleb. T520a & P. Shoemaker \\
\hline Cryphonectria parasitica (Murrill) Barr. EP155 & P. Wang, Univ. of Maryland, Center for Agric. Biotechnology, College Park \\
\hline Botrytis cinerea Pers.:Fr. T515a & V. Higgins, Univ. of Toronto, Dept. of Plant Pathol., Montreal, Canada \\
\hline Septoria lycopersici Speg. T512a & V. Higgins \\
\hline Colletotrichum coccodes (Walir.) Hughes T506 and T508 a & V. Higgins \\
\hline V. albo-atrum Reinke \& Berthier T513 ${ }^{\mathrm{a}}$ & V. Higgins \\
\hline $\begin{array}{l}\text { Fusarium oxysporum Schlechtend.:Fr. f. sp. lycopersici } \\
\text { (Sacc.) Snyder \& Hans T373a }\end{array}$ & J. P. Jones, Gulf Coast Res. \& Ed. Center, Brandenton, FL \\
\hline F. moniliforme Sheld. T436 ${ }^{\mathrm{a}}$ & L. Dunkle, Purdue Univ., Dept. of Botany \& Plant Pathol., W. Lafayette, IN \\
\hline Macrophomina phaesolina Tassi $\mathrm{T} 437^{\mathrm{a}}$ & G. Odvody, Texas A\&M, Agric. Exp. Station, Corpus Christi, TX \\
\hline Stemphylium botryosum Wallr. \#60565 & American Type Culture Collection, Rockville, MD \\
\hline S. solani Weber \#11128 & American Type Culture Collection \\
\hline S. solani \#18792 & American Type Culture Collection \\
\hline Septoria lycopersici $\mathrm{T}_{550}^{\mathrm{a}}$ & M. Gleason, Iowa State Univ., Dept. of Plant Pathol., Ames \\
\hline Nectria haematococca Berk. \& Br. MPVI 6-36 ${ }^{a}$ & H. VanEtten, Univ. of Arizona, Dept. of Plant Pathol., Tucson \\
\hline Pythium aphanidermatum (Edson) Fitz. & M. Stanghellini, Univ. of Arizona, Dept. of Plant Pathol., Tucson \\
\hline Phytophthora infestans (Mont.) deBary T510 ${ }^{\mathrm{a}}$ & R. Jaime-Garcia, Univ. of Arizona, Dept. of Plant Pathol., Tucson \\
\hline Magnaporthe grisea (Hebert) Barr. 4392-1-6 & M. Orbach, Univ. of Arizona, Dept. of Plant Pathol., Tucson \\
\hline Neurospora crassa Shear \& Dodge 74A FGSC 987 & Fungal Genetics Stock Center, Univ. of Kansas Medical Center, Dept. of Micro., Kansas City \\
\hline N. crassa erg-1 FGSC 2721 & Fungal Genetics Stock Center \\
\hline N. crassa erg-2 FGSC 2723 & Fungal Genetics Stock Center \\
\hline N. crassa erg-3 FGSC 2725 & Fungal Genetics Stock Center \\
\hline N. crassa erg-4 FGSC 3654 & Fungal Genetics Stock Center \\
\hline Aspergillus nidulans (Eidam) G. Wint. UCD1 & Fungal Genetics Stock Center \\
\hline
\end{tabular}

${ }^{a}$ VanEtten culture collection number designation. 
The $N$. crassa $\mathrm{ED}_{50}$ values obtained for $\alpha$-tomatine, $\beta_{2}$-tomatine, and tomatidine were subjected to analysis of variance using the GLM procedure (SAS Institute). $\mathrm{ED}_{50}$ values of the ergosterol mutants were compared to the $\mathrm{ED}_{50}$ value of wild type using the Dunnett test at $\alpha=0.05$ (13). Each fungus was assayed three times. Reported values are the average of these three assays.

Isolation and identification of $\alpha$-tomatine degradation products. Fungi were grown for 7 days on 35-mm petri plates containing $2 \mathrm{ml}$ of agar medium supplemented with $20 \mu \mathrm{M} \alpha$-tomatine, a concentration that allowed growth of all fungi. The alkaloids were extracted by placing the mycelium and agar into $15-\mathrm{ml}$ polypropylene tubes with $5 \mathrm{ml}$ of $100 \mathrm{mM} \mathrm{HCl}$ and blending with a Brinkman Polytron tissue homogenizer (Brinkman Instruments, Inc., Westbury, NY). After sitting for $1 \mathrm{~h}$ at $24^{\circ} \mathrm{C}$, the extract was centrifuged for $10 \mathrm{~min}$ at $5,000 \times g$ and the alkaloids were precipitated from the supernatant by the addition of $500 \mu \mathrm{l}$ of $30 \%$ ammonium hydroxide. After a 30-min incubation on ice, the solution was centrifuged at $5,000 \times g$ for $30 \mathrm{~min}$, the supernatant carefully removed, and the pellet dissolved in $50 \mu \mathrm{l}$ of ethanol. Approximately $25 \mu \mathrm{l}$ was spotted onto an aluminum-backed silica gel TLC plate $\left(0.2 \mathrm{~mm}\right.$ thick, Kieselgel $60 \mathrm{~F}_{254}$; EM Separations, Gibbstown, $\mathrm{NJ}$ ) and developed in ethyl acetate/methanol/acetic acid/water (30:20:10:1). The TLC plate was dried, dipped in 30\% sulfuric acid, and placed at $110^{\circ} \mathrm{C}$ for $10 \mathrm{~min} . R_{f}$ values for $\alpha$-tomatine, $\beta_{2^{-}}$ tomatine, and tomatidine were $0.23,0.4$, and 0.75 , respectively.

In some experiments, a compound possessing an $R_{f}$ value of 0.57 was observed on the TLC plates. Silica from a preparative TLC plate in which the unknown compound migrated was removed from the plate, eluted with ethanol, evaporated to dryness for mass spectrum (MS) analysis, and resuspended in deuterated pyridine for nuclear magnetic resonance (NMR). $\alpha$-Tomatine and tomatidine were used as standards for the MS and NMR analyses.

Partial characterization of $\boldsymbol{A}$. solani tomatine-degrading enzymes. A. solani mycelium was scraped from the surface of the agar medium of a 7-day culture and placed in $200 \mathrm{ml}$ of clarified V8 liquid medium (V8 juice medium minus the agar was centrifuged at $10,000 \times g$, the pellet discarded, and the liquid autoclaved). Cultures were shaken at $200 \mathrm{rpm}$ for 3 days at $24^{\circ} \mathrm{C}$. My- celium was harvested onto Miracloth (Calbiochem-Behring, La Jolla, CA) by vacuum, and it and the culture filtrate were used immediately for enzyme purification.

Proteins in the culture filtrate were precipitated by the addition of ammonium sulfate to $80 \%$ saturation and stirring for $1 \mathrm{~h}$ at $24^{\circ} \mathrm{C}$ before centrifuging for $30 \mathrm{~min}$ at $12,000 \times \mathrm{g}$. The pellet was resuspended in $50 \mathrm{ml}$ of $50 \mathrm{mM}$ sodium acetate $(\mathrm{pH} 5.0)$ and dialyzed against 4 liters of the same buffer for $24 \mathrm{~h}$ at $4^{\circ} \mathrm{C}$. The dialyzed proteins were concentrated to $5 \mathrm{ml}$ using an Amicon ultrafiltration cell and a YM-30 filter membrane (Amicon Inc., Beverly, MA). Protein concentration was determined with the BCA protein assay reagent (Pierce Chemical Co., Rockford, IL) using bovine serum albumin as a standard. Enzyme assays were carried out in $500 \mu \mathrm{l}$ of $500 \mu \mathrm{M} \alpha$-tomatine with $50 \mathrm{mM}$ sodium acetate ( $\mathrm{pH}$ 5.0) using $100 \mu \mathrm{g}$ of protein at $24^{\circ} \mathrm{C}$ for $2 \mathrm{~h}$. The alkaloids were precipitated with $50 \mu \mathrm{l}$ of $30 \%$ ammonium hydroxide, centrifuged at $3,000 \times g$ for $15 \mathrm{~min}$ at $24^{\circ} \mathrm{C}$, and analyzed by TLC as described above.

To determine if the $\alpha$-tomatine-degrading enzymes of $A$. solani increased after exposure to $\alpha$-tomatine, $1.0 \mathrm{~g}$ of $A$. solani mycelium from a 3-day culture was incubated in $25 \mathrm{ml}$ of $50 \mathrm{mM}$ sodium acetate ( $\mathrm{pH}$ 5.0) with and without $500 \mu \mathrm{M} \alpha$-tomatine for 0 , $2,4,6,8$, and $24 \mathrm{~h}$. The mycelium was collected by vacuum filtration, washed once with $50 \mathrm{mM}$ sodium acetate $(\mathrm{pH} 5.0)$ with $50 \mathrm{mM} \mathrm{NaCl}$, and homogenized for $1 \mathrm{~min}$ in $25 \mathrm{ml}$ of $50 \mathrm{mM}$ sodium acetate $(\mathrm{pH} 5.0)$ with $50 \mathrm{mM} \mathrm{NaCl}$ and $10 \mathrm{~g}$ of glass beads (50 to 70 U.S. sieve; Sigma Chemical Co.) using a Bead Beater (Biospec Products, Bartlesville, OK). The homogenate was centrifuged for $30 \mathrm{~min}$ at $15,000 \times g$ and the supernatant collected and concentrated to $5 \mathrm{ml}$ using an Amicon ultrafiltration cell and a YM-30 filter (Amicon Inc.). Protein $(100 \mu \mathrm{g})$ from the concentrate was incubated in $500 \mu \mathrm{l}$ of $500 \mu \mathrm{g}$ of $\alpha$-tomatine with $50 \mathrm{mM}$ sodium acetate $\left(\mathrm{pH} \mathrm{5.0)}\right.$ for $2 \mathrm{~h}$ at $24^{\circ} \mathrm{C}$. The alkaloids in the reaction mixture were analyzed as above.

\section{RESULTS}

The sensitivity of fungi to $\alpha$-tomatine and its degradation products. Saprophytic fungi, most nonpathogens of tomato, and

TABLE 2. Fungal sensitivity to $\alpha$-tomatine, $\beta_{2}$-tomatine, and tomatidine and degradation products produced by those fungi

\begin{tabular}{|c|c|c|c|c|c|c|c|}
\hline \multirow[b]{2}{*}{ Isolate } & \multicolumn{3}{|c|}{$\mathrm{ED}_{50}$ (standard deviation) } & \multicolumn{3}{|c|}{ Percent inhibition at $1 \mathrm{mM}$} & \multirow{2}{*}{$\begin{array}{c}\text { Enzymatic } \\
\text { degradation } \\
\text { products }\end{array}$} \\
\hline & $\alpha$-Tomatine & $\beta_{2}$-Tomatine & Tomatidine & $\alpha$-Tomatine & $\beta_{2}$-Tomatine & Tomatidine & \\
\hline Neurospora crassa & $13 \mu \mathrm{M}(2)$ & $122 \mu \mathrm{M}(5)$ & $51 \mu \mathrm{M}(13)$ & 100 & 100 & 100 & $\mathrm{No}^{\mathrm{a}}$ \\
\hline Magnaporthe grisea & $22 \mu \mathrm{M}(3)$ & $31 \mu \mathrm{M}(3)$ & $>1,000 \mu \mathrm{M}$ & 100 & 100 & 17 & No \\
\hline Cryphonectria parasitica & $21 \mu \mathrm{M}(2)$ & $302 \mu \mathrm{M}(6)$ & $81 \mu \mathrm{M}(12)$ & 100 & 100 & 93 & No \\
\hline Nectria haematococca MPVI & $34 \mu \mathrm{M}(2)$ & $80 \mu \mathrm{M}(3)$ & $>1,000 \mu \mathrm{M}$ & 100 & 100 & 17 & No \\
\hline Aspergillus nidulans & $45 \mu \mathrm{M}(5)$ & $98 \mu \mathrm{M}(4)$ & $81 \mu \mathrm{M}$ & 100 & 100 & 92 & No \\
\hline Stemphylium solani $11128^{b}$ & $85 \mu \mathrm{M}(3)$ & $92 \mu \mathrm{M}(3)$ & $300 \mu \mathrm{M}(17)$ & 100 & 79 & 98 & $\mathrm{TD}^{\mathrm{c}}$ \\
\hline Fusarium moniliforme & $93 \mu \mathrm{M}(4)$ & $502 \mu \mathrm{M}(7)$ & $>1,000 \mu \mathrm{M}$ & 93 & 77 & 23 & No \\
\hline Macrophomina phaesolina & $100 \mu \mathrm{M}(3)$ & $>1,000 \mu \mathrm{M}$ & $>1,000 \mu \mathrm{M}$ & 80 & 47 & 44 & No \\
\hline Verticillium dahliae $^{\mathrm{b}}$ & $107 \mu \mathrm{M}(3)$ & $502 \mu \mathrm{M}(6)$ & $>1,000 \mu \mathrm{M}$ & 90 & 74 & 43 & $\mathrm{TD}$ \\
\hline Botrytis cinerea & $143 \mu \mathrm{M}(3)$ & $600 \mu \mathrm{M}(7)$ & $>1,000 \mu \mathrm{M}$ & 100 & 61 & 16 & TD \\
\hline Stemphylium solani $18792^{\mathrm{b}}$ & $302 \mu \mathrm{M}(7)$ & $301 \mu \mathrm{M}(6)$ & $304 \mu \mathrm{M}(12)$ & 100 & 82 & 85 & TD \\
\hline Phytophthora infestans ${ }^{\mathrm{b}}$ & $303 \mu \mathrm{M}(6)$ & Not tested & $>1,000 \mu \mathrm{M}$ & 91 & Not tested & 38 & No \\
\hline Colletotrichum coccodes $\mathrm{T}^{506^{\mathrm{b}}}$ & $394 \mu \mathrm{M}(8)$ & $>1,000 \mu \mathrm{M}$ & $>1,000 \mu \mathrm{M}$ & 51 & 33 & 14 & TD \\
\hline Stemphylium botryosum ${ }^{\mathrm{b}}$ & $420 \mu \mathrm{M}(12)$ & $502 \mu \mathrm{M}(9)$ & $>1,000 \mu \mathrm{M}$ & 70 & 56 & 16 & TD \\
\hline Colletotrichum coccodes $\mathrm{T} 508^{\mathrm{b}}$ & $423 \mu \mathrm{M}(9)$ & $>1,000 \mu \mathrm{M}$ & $>1,000 \mu \mathrm{M}$ & 54 & 30 & 11 & TD \\
\hline Pythium aphanidermatum ${ }^{\mathrm{b}}$ & $433 \mu \mathrm{M}(9)$ & Not tested & $451 \mu \mathrm{M}(15)$ & 100 & Not tested & 93 & No \\
\hline Verticillium albo-atrum ${ }^{\mathrm{b}}$ & $439 \mu \mathrm{M}(7)$ & $>1,000 \mu \mathrm{M}$ & $>1,000 \mu \mathrm{M}$ & 65 & 31 & 0 & $\beta_{2}{ }^{d}$ \\
\hline Alternaria alternata f. sp. lycopersici ${ }^{\mathrm{b}}$ & $493 \mu \mathrm{M}(8)$ & $>1,000 \mu \mathrm{M}$ & $>1,000 \mu \mathrm{M}$ & 73 & 35 & 08 & TD \\
\hline Fusarium oxysporum f. sp. lycopersici ${ }^{\text {b }}$ & $912 \mu \mathrm{M}(14)$ & $>1,000 \mu \mathrm{M}$ & $>1,000 \mu \mathrm{M}$ & 53 & 35 & 11 & TD \\
\hline Alternaria solani ${ }^{\mathrm{b}}$ & $>1,000 \mu \mathrm{M}$ & $903 \mu \mathrm{M}(14)$ & $>1,000 \mu \mathrm{M}$ & 47 & 61 & 35 & $\mathrm{TD}$ \\
\hline Alternaria alternata ${ }^{\mathrm{b}}$ & $>1,000 \mu \mathrm{M}$ & $>1,000 \mu \mathrm{M}$ & $>1,000 \mu \mathrm{M}$ & 45 & 15 & 10 & TD \\
\hline Septoria lycopersici $\mathrm{T} 550^{\mathrm{b}}$ & $>1,000 \mu \mathrm{M}$ & $>1,000 \mu \mathrm{M}$ & $>1,000 \mu \mathrm{M}$ & 41 & 21 & 7 & $\beta_{2}$ \\
\hline Septoria lycopersici $\mathrm{T} 512^{\mathrm{b}}$ & $>1,000 \mu \mathrm{M}$ & $>1,000 \mu \mathrm{M}$ & $>1,000 \mu \mathrm{M}$ & 10 & 0 & 0 & $\beta_{2}$ \\
\hline
\end{tabular}

a No = none detected.

b Pathogen on tomato.

c $\mathrm{TD}=$ tomatidine.

d $\beta_{2}=\beta_{2}$-tomatine. 
the tomato pathogens $S$. solani isolate 11128 and $V$. dahliae were highly sensitive to $\alpha$-tomatine, with little or no growth at concentrations higher than $200 \mu \mathrm{M}$ (e.g., Aspergillus nidulans) (Fig. 2A). All fungi with $\mathrm{ED}_{50}$ values $\leq 107 \mu \mathrm{M}$ (Table 2) had this pattern of response to this compound. Most showed large increases in growth inhibition with relatively small increases in $\alpha$-tomatine concentration before an asymptotic threshold was achieved at 95 to $100 \%$ growth inhibition. For most of the tomato pathogens tested there was a moderate inhibition of growth with increasing concentrations of $\alpha$-tomatine, but a complete inhibition of growth was not obtained at the concentrations tested (e.g., Colletotrichum coccodes) (Fig. 2B and Table 2). Percent inhibition at $1 \mathrm{mM} \alpha$ tomatine was used to compare the relative toxicity of $\alpha$-tomatine (and its breakdown products) for fungi whose $\mathrm{ED}_{50}$ values were $>1 \mathrm{mM}$ (Table 2). A third type of response was observed only for Septoria lycopersici $\mathrm{T} 512$, which revealed little inhibition at all concentrations of $\alpha$-tomatine tested (Fig. 2C).

The fungal isolates were also tested for sensitivity to $\beta_{2}$-tomatine and tomatidine, the hydrolysis products of $\alpha$-tomatine (Fig. 1). Although $\beta_{2}$-tomatine was generally less toxic than $\alpha$ tomatine (Table 2 ), the relative sensitivity to $\beta_{2}$-tomatine compared with that to $\alpha$-tomatine varied greatly. For example, $S$. solani and A. solani $\mathrm{ED}_{50}$ values were within $10 \%$ of those observed for $\alpha$-tomatine, while $V$. dahliae and Cryphonectria parasitica were 5 and 15 times as tolerant of $\beta_{2}$-tomatine than of $\alpha$-tomatine, respectively. Almost all fungi were more tolerant of the aglycone tomatidine than of $\alpha$-tomatine, but the degree of tolerance varied, especially among the nonpathogens of tomato as can be seen in

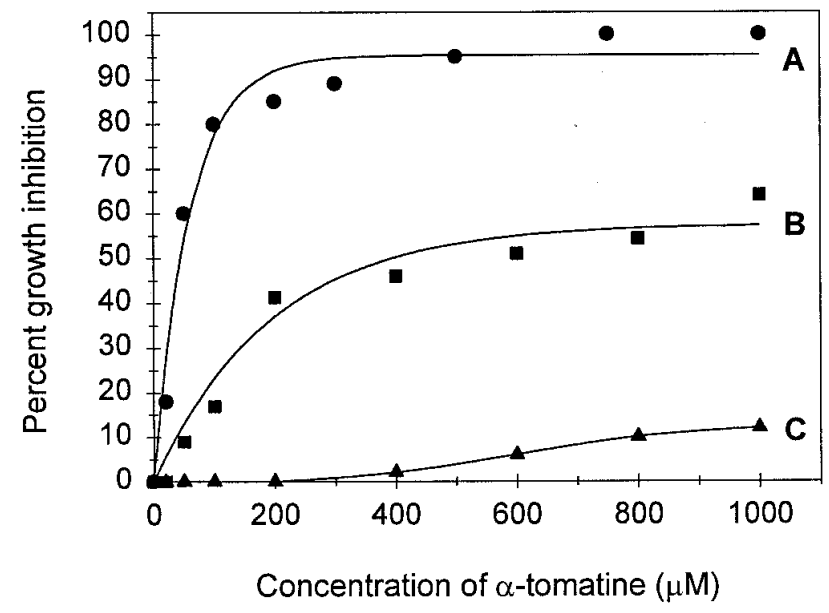

Fig. 2. Growth responses observed for selected representatives of saprophytic fungi, nonpathogens of tomato, and tomato pathogens when grown on medium supplemented with $\alpha$-tomatine. A, Aspergillus nidulans; $\mathbf{B}$, Verticillium albo-atrum; and C, Septoria lycopersici isolate T512. Lines represent the growth curve, as determined by NLIN program for nonlinear regression (SAS Institute Inc.), that best fit the observed data points.

TABLE 3. Sensitivity of Neurospora crassa sterol mutants to $\alpha$-tomatine and its derivatives $\left(\mathrm{ED}_{50}\right)$

\begin{tabular}{|c|c|c|c|}
\hline Isolate $^{a}$ & $\alpha$-Tomatine & $\beta_{2}$-Tomatine & Tomatidine \\
\hline Neurospora crassa 74A & $15 \mu \mathrm{M}(2)^{\mathrm{b}}$ & $120 \mu \mathrm{M}(4)$ & $51 \mu \mathrm{M}(3)$ \\
\hline Neurospora crassa erg-1 & $31 \mu \mathrm{M}(3)^{\mathrm{c}}$ & $125 \mu \mathrm{M}(4)$ & $50 \mu \mathrm{M}(3)$ \\
\hline Neurospora crassa erg-2 & $51 \mu \mathrm{M}(3)^{\mathrm{c}}$ & $313 \mu \mathrm{M}(6)^{\mathrm{c}}$ & $100 \mu \mathrm{M}(5)^{\mathrm{c}}$ \\
\hline Neurospora crassa erg-3 & $79 \mu \mathrm{M}(4)^{\mathrm{c}}$ & $329 \mu \mathrm{M}(7)^{\mathrm{c}}$ & $52 \mu \mathrm{M}(4)$ \\
\hline Neurospora crassa erg-4 & $75 \mu \mathrm{M}(3)^{\mathrm{c}}$ & $172 \mu \mathrm{M}(6)^{\mathrm{c}}$ & $97 \mu \mathrm{M}(4)^{\mathrm{c}}$ \\
\hline
\end{tabular}

a All isolates were completely inhibited by $1 \mathrm{mM} \alpha$-tomatine, $\beta_{2}$-tomatine, and tomatidine except the $N$. crassa erg-3 mutant on $\beta_{2}$-tomatine, which was inhibited $98 \%$.

${ }^{\mathrm{b}}$ Numbers in parentheses represent standard deviation.

${ }^{c}$ Value is statistically different from wild-type $\mathrm{ED}_{50}$ value using the Dunnett test at $\alpha=0.05$. both the $\mathrm{ED}_{50}$ values and their percent inhibition at $1 \mathrm{mM}$ tomatidine (Table 2). Seventeen of the twenty-three fungal isolates tested were highly tolerant $\left(\mathrm{ED}_{50}>1 \mathrm{mM}\right)$ as compared with their sensitivity toward $\alpha$-tomatine and, in all of these cases, tomatidine was less toxic than $\alpha$-tomatine. However, N. crassa, C. parasitica, Aspergillus nidulans, and the tomato pathogens $S$. solani and Pythium aphanidermatum were either moderately or largely inhibited by the aglycone (Table 2). Tomatidine was more toxic than $\beta_{2}$-tomatine to Aspergillus nidulans, C. parasitica, and N. crassa.

To test the effect of membrane sterol composition on the sensitivity to $\alpha$-tomatine and its derivatives, the toxicity of these compounds was tested on four ergosterol (erg) mutants of $N$. crassa (Table 3). Mutations in the genes of the ergosterol biosynthetic pathway increased the $\alpha$-tomatine and $\beta_{2}$-tomatine tolerance of $N$. crassa, except for the isolate carrying the erg-1 mutation whose tolerance to $\beta_{2}$-tomatine did not statistically differ from wild type (Table 3 ). The $N$. crassa mutants erg-2 and erg-4 were twice as tolerant of tomatidine as the wild type and were statistically different from wild type. Growth of all isolates was totally inhibited at $1 \mathrm{mM} \alpha$-tomatine, $\beta_{2}$-tomatine, and tomatidine except for $\mathrm{erg}$-3, which had a slight amount of growth $(2 \%)$ at this concentration of $\beta_{2}$-tomatine.

Fungal degradation of $\alpha$-tomatine. The degradation products of $\alpha$-tomatine produced by the fungi tested are listed in Table 2. No degradation products were detected from Aspergillus nidulans, C. parasitica, F. moniliforme, M. grisea, Macrophomina phaeso-

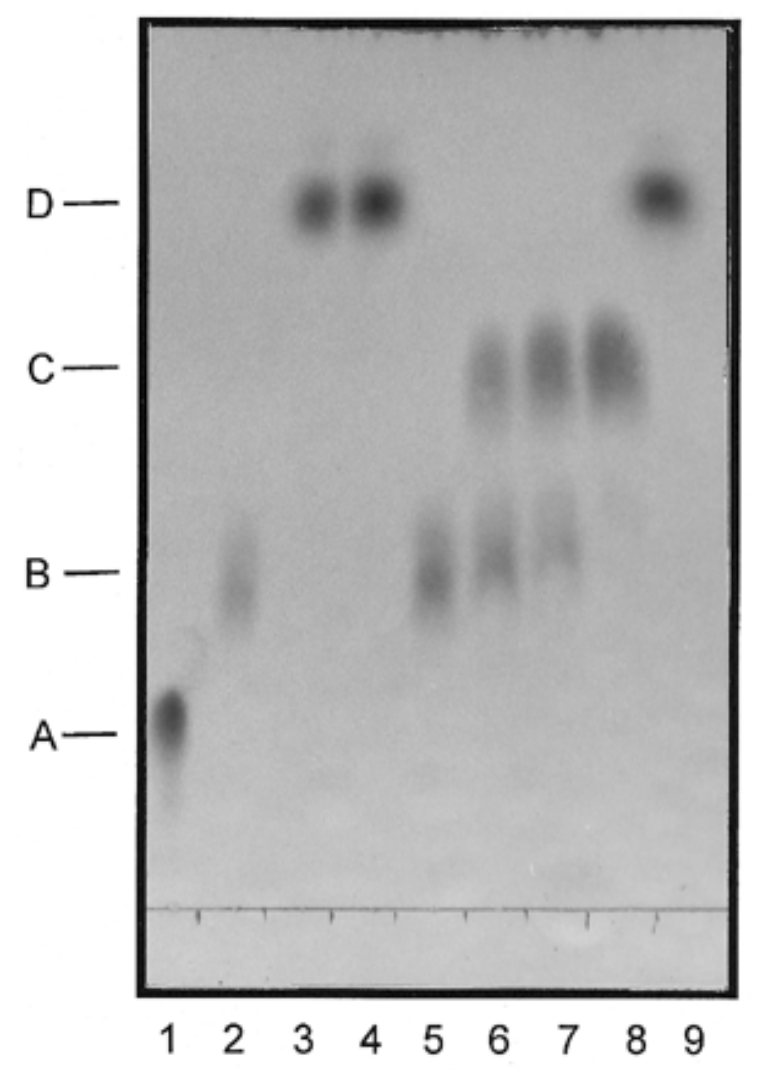

Fig. 3. Thin-layer chromatography (TLC) plate showing degradation products of $\alpha$-tomatine produced by Alternaria solani. Approximately $10 \mu \mathrm{g}$ of the alkaloid standards and extracts was spotted onto each lane of the TLC plate. Top of figure represents the solvent front. Lane 1, $\alpha$-tomatine standard $\left(R_{f}=0.23\right)$; lane $2, \beta_{2}$-tomatine standard $\left(R_{f}=0.4\right)$; lane 3 , tomatidine standard $\left(R_{f}=0.75\right)$; lane 4 , reaction products after incubating $\alpha$-tomatine for $2 \mathrm{~h}$ with protein from culture filtrate of $A$. solani grown in the absence of $\alpha$ tomatine; lane 5 , reaction products after incubating $\alpha$-tomatine with mycelial extracts for $2 \mathrm{~h}$ from mycelium that was not grown in the presence of $\alpha$-tomatine; and lanes 6 through 9 , reaction products after incubating $\alpha$-tomatine with mycelial extracts for $2 \mathrm{~h}$ from mycelium that was grown in the presence of $\alpha$-tomatine for $2 \mathrm{~h}$ (lane 6), $4 \mathrm{~h}$ (lane 7), $8 \mathrm{~h}$ (lane 8), and $24 \mathrm{~h}$ (lane 9). 
lina, Nectria haematococca, $N$. crassa, Pythium aphanidermatum, and $P$. infestans when these fungi had completely grown through and across the agar surface on medium supplemented with $20 \mu \mathrm{M}$ $\alpha$-tomatine. Septoria lycopersici and V. albo-atrum degraded $\alpha$ tomatine to $\beta_{2}$-tomatine. All other isolates were able to degrade $\alpha$ tomatine to tomatidine.

Degradation of $\alpha$-tomatine by $\boldsymbol{A}$. solani. An ammonium sulfate precipitation of the culture filtrate of $A$. solani grown in the absence of $\alpha$-tomatine, when incubated for $2 \mathrm{~h}$ with $\alpha$-tomatine (Fig. 3, lane 4) and $\beta_{2}$-tomatine (data not shown), caused the release of tomatidine, indicating that enzymes required for the hydrolysis of $\alpha$-tomatine to tomatidine are constitutive and secreted from A. solani. To determine if tomatinase activity increased by pretreatment with $\alpha$-tomatine, a final concentration of $500 \mu \mathrm{M} \alpha$ tomatine was added to a 3-day liquid culture, and after $0,2,4,8$, and $24 \mathrm{~h}$, crude protein extracts of the mycelium were assayed for $\alpha$-tomatine-degrading activity by incubating the extracts for a reaction period of $2 \mathrm{~h}$ with $\alpha$-tomatine. With protein extracted from mycelium not previously exposed to $\alpha$-tomatine, $\beta_{2}$-tomatine was the only degradation product detected after the 2-h incubation period (Fig. 3, lane 5), unlike extracts from culture filtrates that were observed to degrade $\alpha$-tomatine to tomatidine. Crude protein extracts from $A$. solani mycelium collected after 2 to $8 \mathrm{~h}$ after exposure to $\alpha$-tomatine converted $\alpha$-tomatine to an unknown derivative (Fig. 3, lanes 6 to 8). Tomatidine was the only alkaloid detected by TLC (Fig. 3, lane 9) with the protein extract obtained from mycelium $24 \mathrm{~h}$ after exposure to $\alpha$-tomatine.

Identification of $\delta$-tomatine. The $500-\mathrm{MHz}$ proton NMR spectrum of the unknown compound (Fig. 3, lanes 6 to 8 ) in pyridine when compared with the spectrum of $\alpha$-tomatine (42) strongly suggested that this compound was $\delta$-tomatine (Fig. 1). The aglycone peaks included methyls at delta $0.65(s, \mathrm{H}-19), 0.80(d, \mathrm{~J}=6$ $\mathrm{Hz}, \mathrm{H}-27), 0.85$ ( $s, \mathrm{H}-18)$, and 1.07 (d, J = 7 Hz, H-21); protons alpha to $\mathrm{N}$ at $2.82(m, \mathrm{H}-26$ beta $)$ and $2.93(t, \mathrm{~J}=11 \mathrm{~Hz}, \mathrm{H}-$ 26alpha); and protons alpha to $\mathrm{O}$ at $3.82(\mathrm{~m}, \mathrm{H}-3)$ and $4.17(\mathrm{~m}, \mathrm{H}-$ 16). There was only one anomeric proton at delta $4.95(d, \mathrm{~J}=7$ $\left.\mathrm{Hz}, 1^{\prime}\right)$, with other sugar protons at $3.97\left(m, 5^{\prime}\right), 4.15\left(m, 3^{\prime}\right), 4.25$ $\left(m, 6^{\prime}\right), 4.40\left(m, 2^{\prime}\right), 4.50\left(m, 6^{\prime}\right)$, and $4.61\left(b r s, 4^{\prime}\right)$. There was a single major parent ion peak at 577 when MS was performed on this compound that corresponded to the predicted molecular weight of $\delta$-tomatine.

\section{DISCUSSION}

Some of the tomato pathogens used in the current study have been shown previously to be tolerant of $\alpha$-tomatine (2). Although our assay conditions were different, we also observed that most tomato pathogens were tolerant of this compound, while saprophytes and pathogens of hosts other than tomato were sensitive to $\alpha$-tomatine (Table 2 and Fig. 4). Although some tomato pathogens were found to be fairly sensitive to $\alpha$-tomatine ( $S$. solani and $V$. dahliae), their modes of pathogenicity may offer an explanation for these observations. S. solani is a leaf pathogen, and leaves may contain $\alpha$-tomatine at levels of up to $1 \mathrm{mM}$. However, like another leaf pathogen, Cladosporium fulvum, that is also quite sensitive to $\alpha$-tomatine (12), $S$. solani grows within the intercellular space and middle lamella of the leaf (11). Here, the advancing hyphae may not come into contact with $\alpha$-tomatine, as this compound is stored in cell vacuoles (29). A similar situation may hold true for $V$. alboatrum and $V$. dahliae because, as wilt pathogens, they are limited mainly to the xylem tissue. These modes of pathogenicity differ from Septoria lycopersici, which directly penetrates the leaf (35), and $A$. solani, which can directly penetrate the leaf and produce a toxin that may result in the release of $\alpha$-tomatine (30).

All of the tomato pathogens tested were able to degrade $\alpha$-tomatine except for Pythium aphanidermatum and P. infestans (Table 2).

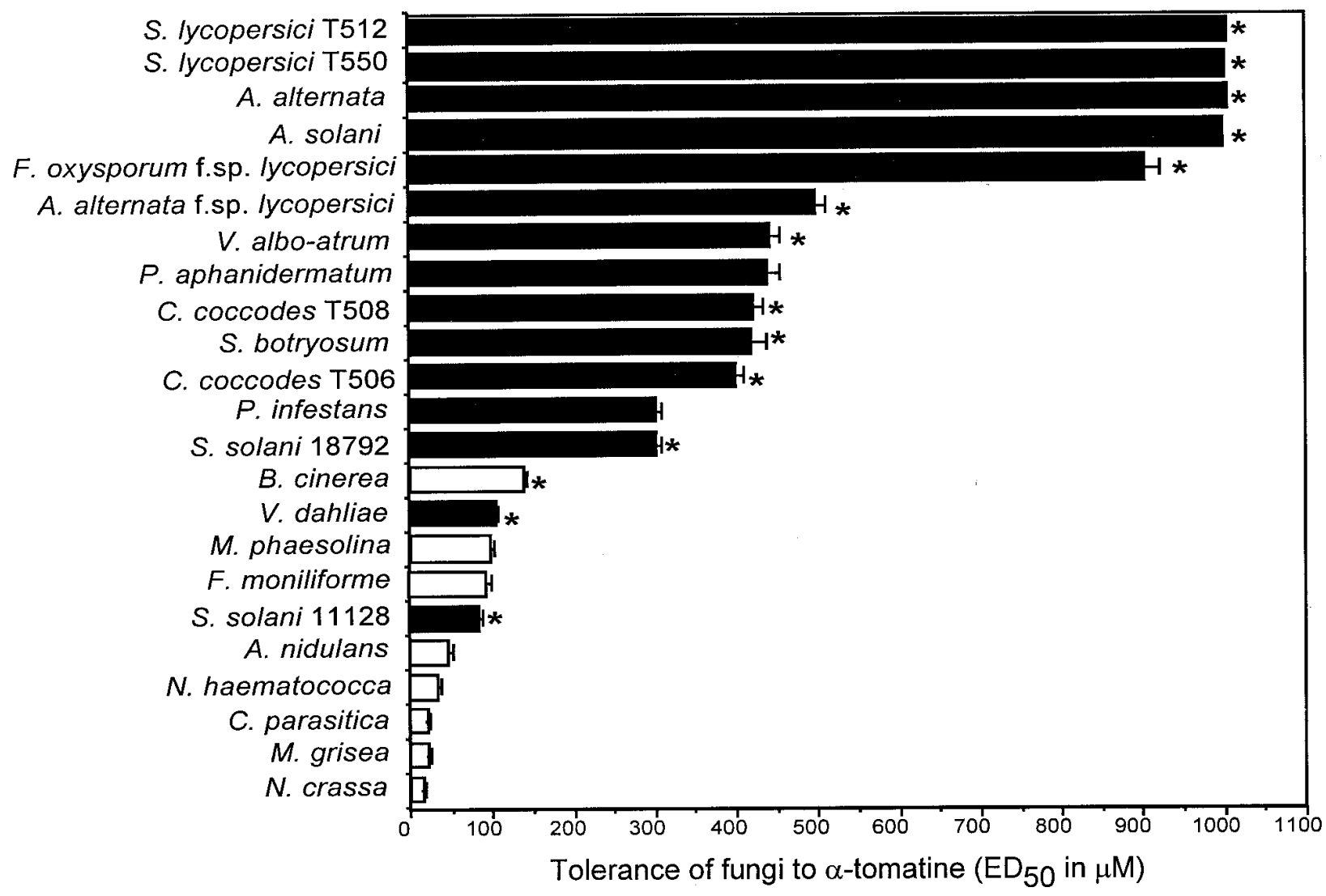

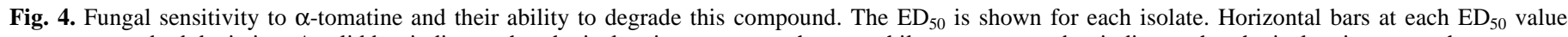

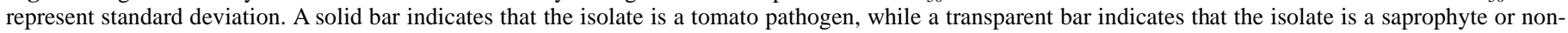
pathogen of tomato. An asterisk indicates that the isolate has the ability to degrade $\alpha$-tomatine. 
This is the first report that A. alternata, A. alternata f. sp. lycopersici, Colletotrichum coccodes, $S$. solani, and V. dahliae are able to degrade this compound. Most of the tomato pathogens degraded $\alpha$-tomatine to tomatidine (Table 2). However, two tomato pathogens, Septoria lycopersici and V. albo-atrum, form $\beta_{2}$-tomatine as the final product as previously reported $(1,26)$. One isolate that was considered to be a nonpathogen of tomato, $B$. cinerea from grape, was able to degrade $\alpha$-tomatine to tomatidine. This isolate, however, has not been tested for its ability to parasitize tomato.

Based on the available data, there does not seem to be a common enzymatic mechanism by which tomato pathogens degrade $\alpha$-tomatine, since different species remove a single sugar moiety (Septoria lycopersici [1], V. albo-atrum [26]), two or more sugars sequentially (A. solani $[33$, this study], Colletotrichum coccodes $[\mathrm{R}$. W. Sandrock, unpublished data]), or the tetrasaccharide moiety as a single unit from $\alpha$-tomatine (B. cinerea [40], $F$. oxysporum f. sp. lycopersici [16]). Degradation of $\alpha$-tomatine by $A$. solani was previously reported to occur via sequential hydrolysis of the four sugar residues in a crude enzyme preparation from tomato fruit pulp tissues (33). Since ripening tomato fruit also has tomatinase activity (28) and no standards were available for the verification of the breakdown products, we have retested the previous results. For the current study, mycelium of $A$. solani was grown in liquid culture both in the presence and absence of $\alpha$ tomatine, and it was shown that the culture filtrates of $A$. solani contain tomatinase activity and that the tomatinase activity within the mycelium increased after exposure to $\alpha$-tomatine (Fig. 3). $\alpha$ Tomatine was degraded to $\beta_{2}$-tomatine, the previously unidentified intermediate $\delta$-tomatine, and tomatidine. These results do not indicate the number of enzymes involved in the degradation of $\alpha$ tomatine. Since some saponinases are able to hydrolyze more than one glycosidic linkage (43), determination of the number of enzymes involved in the degradation of $\alpha$-tomatine to tomatidine by A. solani requires further biochemical characterization.

Previous researchers have suggested that the hydrolysis products of $\alpha$-tomatine are less toxic because of their inability to complex with membrane-bound $3 \beta$-hydroxy sterols $(3,23,36)$. In this study, $\beta_{2}$-tomatine and the aglycone tomatidine were generally less toxic, but these compounds were inhibitory to some fungi (Table 2). In addition, $\alpha$-tomatine was inhibitory to $P$. infestans and Pythium aphanidermatum, which lack these sterols. Assuming that there are few sterols in the medium that these two fungi can utilize, this suggests that $\alpha$-tomatine and its derivatives may possess additional properties other than binding to $3 \beta$-hydroxy sterols that render them toxic. If this is true, it is possible that tomato pathogens have acquired additional means to tolerate this other mode of toxicity. Of particular interest are Septoria lycopersici and V. albo-atrum, which are not able to degrade $\beta_{2}$-tomatine, yet are very tolerant of this compound compared with most of the saprophytes and nonpathogens of tomato that are unable to degrade $\beta_{2}$-tomatine. Tomato pathogens may have evolved an additional means to tolerate a tomatine-like structure that is not based on enzymatic alteration of the saponin. Such "nondegradative" tolerance towards plant phytoalexins and polyene antibiotics that interact with sterols or membrane lipids has been identified as a possible means to overcome the toxicity of these compounds (810,20,21).

Nevertheless, both the structural and quantitative traits of the sterols present in a membrane can affect the saponin-sterol interaction in vitro $(22,23,36)$. The differences in the tolerance of the ergosterol mutants of $N$. crassa to $\alpha$-tomatine and its metabolites indicate that changes in the type of sterol can effectively increase tolerance (Table 3). Ergosterol, a 3 $\beta$-hydroxy sterol, is the major sterol component of $N$. crassa and constitutes $80 \%$ of the total sterol content (14). erg mutants of $N$. crassa lack ergosterol due to mutations in genes involved in the ergosterol biosynthetic pathway and accumulate the $3 \beta$-hydroxy sterols fecosterol (erg-1),
24(28) dehydroergosterol (erg-2), $\Delta^{8,14}$ sterols (erg-3), and zymosterol (erg-4) $(14,18)$. Although the interaction of these sterol intermediates with $\alpha$-tomatine in vitro is unknown, results from these in vivo tests suggest that the membranes are altered so that they are less sensitive to these alkaloids, suggesting different degrees of interaction with the different sterols. In addition, however, other research has shown that the presence of glycolipids in cholesterol-containing membranes results in an increase in the membrane-disrupting properties of $\alpha$-tomatine, not because of the structure and composition of the glycolipid, but because of the concentration of the glycolipids (23). Based on these data, it is possible that alterations in the sterol and lipid compositions of the tomato pathogens may protect them from the residual toxic effects of the degradation products of $\alpha$-tomatine.

With the discovery that the avenacinase gene is essential for the pathogenicity of G. graminis var. avenae (5), it will be interesting to assess the importance of $\alpha$-tomatine degradation by pathogens of tomato. This assessment should more easily be addressed using F. oxysporum f. sp. lycopersici and Septoria lycopersici, since it appears that a single enzyme in each of these species is involved in the degradation of $\alpha$-tomatine $(24,31)$. Moreover, the gene encoding the $\beta_{2}$-tomatinase gene from Septoria lycopersici has been cloned, and this should facilitate the formation of " $\beta_{2}$-tomatinasedeficient" mutants via gene disruption $(24,25,31)$. Formation of tomatinase-deficient mutants in these fungi will also provide information as to whether a nondegradative tolerance mechanism exists and, if so, whether this tolerance is to $\alpha$-tomatine, the degradation products of $\alpha$-tomatine produced by these fungi, or both.

\section{ACKNOWLEDGMENTS}

This project was supported, in part, by DOE/ER grants 20239 and 14038. We thank E. Mizubuti and G. Churchill for statistical advice; S. Soby for helpful comments about the manuscript; and L. Dunkle, D. Gilchrist, M. Gleason, V. Higgins, R. Jaime-Garcia, J. P. Jones, G. Odvody, M. Orbach, P. Shoemaker, M. Stenghellini, and P. Wang for supplying the fungal cultures used in these experiments. We also thank T. McClure and the Southwest Environmental Health Sciences Center Analytical Core Laboratory (NIH grant ES06694) for mass spectroscopy and R. Bates and J. Burns, Department of Chemistry, University of Arizona, for the nuclear magnetic resonance spectrum analysis.

\section{LITERATURE CITED}

1. Arneson, P. A., and Durbin, R. D. 1967. Hydrolysis of tomatine by Septoria lycopersici: A detoxification mechanism. Phytopathology 57:13581360.

2. Arneson, P. A., and Durbin, R. D. 1968. The sensitivity of fungi to $\alpha$ tomatine. Phytopathology 58:536-537.

3. Arneson, P. A., and Durbin, R. D. 1968. Studies on the mode of action of tomatine as a fungitoxic agent. Plant Physiol. 43:683-686.

4. Belic, I., and Karlovsek, M. 1981. Microbial conjugation of tomatine. J. Steroid Biochem. 14:229-231.

5. Bowyer, P., Clarke, B. R., Lunness, P., Daniels, M. J., and Osbourn, A. E. 1995. Host range of a plant pathogenic fungus determined by a saponin detoxifying enzyme. Science 267:371-374.

6. Caten, C. E. 1974. Intra-racial variation in Phytophthora infestans and adaptation to field resistance for potato blight. Ann. Appl. Biol. 77:259270.

7. Crombie, W. M. L., Crombie, L., Green, J. B., and Lucas, J. A. 1986. Pathogenicity of 'take-all' fungus to oats: Its relationship to the concentration and detoxification of the four avenacins. Phytochemistry 25: 2075-2083.

8. Defago, G., and Kern, H. 1983. Induction of Fusarium solani mutants insensitive to tomatine, their pathogenicity and aggressiveness to tomato fruits and pea plants. Physiol. Plant Pathol. 22:29-37.

9. Defago, G., Kern, H., and Sedlar, L. 1983. Genetic analysis of tomatine insensitivity, sterol content and pathogenicity for green tomato fruits in mutants of Fusarium solani. Physiol. Plant Pathol. 22:39-43.

10. Denny, T. P., and VanEtten, H. D. 1983. Characterization of an inducible nondegradative tolerance of Nectria haematococca MPVI to phytoalexins. J. Gen. Microbiol. 129:2903-2913.

11. Diener, U. L. 1955. Host-penetration and pathological histology in gray 
leaf spot of tomato. Phytopathology 45:654-658.

12. Dow, J. M., and Callow, J. A. 1978. A possible role for $\alpha$-tomatine in the varietal-specific resistance of tomato to Cladosporium fulvum. Phytopathol. Z. 92:211-216.

13. Dunnett, C. W. 1955. A multiple comparisons procedure for comparing several treatments with a control. J. Am. Stat. Assoc. 509:1096-1121.

14. Ellis, S. W., Rose, M. E., and Grindle, M. 1991. Identification of a sterol mutant of Neurospora crassa deficient in delta-14-15 reductase activity. J. Gen. Microbiol. 137:2627-2630.

15. Eltayeb, E. A., and Roddick, J. G. 1984. Changes in the alkaloid content of developing fruits of tomato (Lycopersicon esculentum Mill.). I. Analyses of cultivars and mutants with different ripening characteristics. J. Exp. Bot. 35:252-260.

16. Ford, J. E., McCance, D. J., and Drysdale, R. B. 1977. The detoxification of $\alpha$-tomatine by Fusarium oxysporum f. sp. lycopersici. Phytochemistry 16:545-546.

17. Gallardo, F., and Boethel, D. J. 1990. Effects of the allelochemical $\alpha$ tomatine on the soybean looper Lepidoptera noctuidae. J. Entomol. Sci. 25:376-382.

18. Grindle, M. 1973. Sterol mutants of Neurospora crassa: Their isolation, growth characteristics and resistance to polyene antibiotics. Mol. Gen. Genet. 120:283-290.

19. Jadhav, S. J., Raghubir, P. S., and Salunkhe, D. K. 1981. Naturally occurring toxic alkaloids in foods. Pages 21-104 in: Critical Reviews in Toxicology, vol. 9. L. Golberg, ed. CRC Press, Inc., Boca Raton, FL.

20. Kasbekar, D. P. 1994. Nondegradative pisatin-resistance in Dictyostelium discoideum, Neurospora crassa, and Nectria haematococca: Similarities and differences. J. Biosci. 19:529-536.

21. Kasbekar, D. P., and Papavinasasundaram, K. G. 1992. An inducible, nondegradative phytoalexin-resistance mechanism in Dictyostelium discoideum is suppressed by mutations that alter membrane sterol composition. Appl. Environ. Microbiol. 58:2071-2074.

22. Keukens, E. A. J., de Vrije, T., Fabrie, C. H. J. P., Demel, R. A., Jongen, W. M. F., and de Kruijff, B. 1992. Dual specificity of sterol-mediated glycoalkaloid induced membrane disruption. Biochim. Biophys. Acta 1110:127-136.

23. Keukens, E. A. J., de Vrije, T., Vandenboom, C., Dewaard, P., Plasman, H. H., Thiel, F., Chupin, V., Jongen, W. M. F., and de Kruijff, B. 1995. Molecular basis of glycoalkaloid induced membrane disruption. Biochim. Biophys. Acta 1240:216-228.

24. Lairini, K., Perez Espinosa, A., Pineda, M., and Ruiz Rubio, M. 1996. Purification and characterization of tomatinase from Fusarium oxysporum f. sp. lycopersici. Appl. Environ. Microbiol. 62:1604-1609.

25. Osbourn, A., Bowyer, P., Lunness, P., Clarke, B., and Daniels, M. 1995. Fungal pathogens of oat roots and tomato leaves employ closely related enzymes to detoxify different host plant saponins. Mol. Plant-Microbe Interact. 8:971-978.

26. Pegg, G. F., and Woodward, S. 1986. Synthesis and metabolism of $\alpha-$ tomatine in tomato isolines in relation to resistance to Verticillium alboatrum. Phys. Mol. Plant Pathol. 28:187-201.
27. Price, K. R., Johnson, I. T., and Fenwick, G. R. 1987. The chemistry and biological significance of saponins in foods and feedingstuffs. Pages 27135 in: Critical Reviews in Food Science and Nutrition, vol. 26. T. E. Furia, ed. CRC Press, Inc., Boca Raton, FL.

28. Roddick, J. G. 1974. The steroidal glycoalkaloid $\alpha$-tomatine. Phytochemistry 13:9-25.

29. Roddick, J. G. 1976. Intracellular distribution of the steroidal glycoalkaloid $\alpha$-tomatine in Lycopersicon esculentum fruit. Phytochemistry 15: 475-477.

30. Rotem, J. 1994. The Genus Alternaria. Biology, Epidemiology, and Pathogenicity. The American Phytopathological Society, St. Paul, MN.

31. Sandrock, R. W., DellaPenna, D., and VanEtten, H. D. 1995. Purification and characterization of $\beta_{2}$-tomatinase, an enzyme involved in the degradation of $\alpha$-tomatine and isolation of the gene encoding $\beta_{2}$-tomatinase from Septoria lycopersici. Mol. Plant-Microbe Interact. 8:960-970.

32. Sato, Y., and Hayakawa, S. 1964. The microbial hydroxylation of tomatidine. J. Org. Chem. 29:198-201.

33. Schlösser, E. 1975. Role of saponins in antifungal resistance. IV. Tomatin-dependent development of species of Alternaria on tomato fruits. Acta Phytopathol. 10:77-87.

34. Schulz, G., and Sander, H. 1957. Über cholesterin-tomatid eine neue molekulverbindung zur analyse und präparativen gewinnung von steroiden. Z. Physiol. Chem. 308:122-126.

35. Sohi, H. S., and Sokhi, S. S. 1972. Morphological, physiological and pathological studies in Septoria lycopersici. Indian Phytopathol. 26:666673.

36. Steel, C. C., and Drysdale, R. B. 1988. Electrolyte leakage from plant and fungal tissues and disruption of liposome membranes by $\alpha$-tomatine. Phytochemistry 27:1025-1030.

37. Turner, E. M. 1961. An enzymic basis for pathogen specificity in Ophiobolus graminis. J. Exp. Bot. 12:169-175.

38. Valent, B., Farrall, L., and Chumley, F. G. 1991. Magnaporthe grisea genes for pathogenicity and virulence identified through a series of backcrosses. Genetics 127:87-102.

39. VanEtten, H. D., Mansfield, J. W., Bailey, J. A., and Farmer, E. E. 1994. Two classes of plant antibiotics: Phytoalexins versus "phytoanticipins." Plant Cell 9:1191-1192.

40. Verhoeff, K., and Liem, J. I. 1975. Toxicity of tomatine to Botrytis cinerea, in relation to latency. Phytopathol. Z. 82:333-338.

41. Vogel, H. J. 1964. Distribution of lysine pathways among fungi: Evolutionary implications. Am. Nat. 98:435.

42. Willker, W., and Leibfritz, D. 1992. Complete assignment and conformational studies of tomatine and tomatidine. Magn. Reson. Chem. 30: 645-650.

43. Wubben, J. P., Price, K. R., Daniels, M. J., and Osbourn, A. E. 1996. Detoxification of oat leaf saponins by Septoria avenae. Phytopathology 86:986-992.

44. Yelton, M. M., Hamer, J. E., and Timberlake, W. E. 1984. Transformation of Aspergillus nidulans by using a trpC plasmid. Proc. Natl. Acad. Sci. U.S.A. 81:1470-1474. 